medRxiv preprint doi: https://doi.org/10.1101/2021.05.03.21256546; this version posted May 4, 2021. The copyright holder for this preprint (which was not certified by peer review) is the author/funder, who has granted medRxiv a license to display the preprint in perpetuity.

It is made available under a CC-BY 4.0 International license .

\title{
City-wide school-located influenza vaccination: a retrospective cohort study
}

Jade Benjamin-Chung ${ }^{1,2}$, Benjamin F. Arnold ${ }^{3}$, Kunal Mishra ${ }^{2}$, Chris J. Kennedy ${ }^{2}$, Anna Nguyen ${ }^{2}$, Nolan N. Pokpongkiat ${ }^{2}$, Stephanie Djajadi ${ }^{2}$, Anmol Seth ${ }^{2}$, Nicola P. Klein ${ }^{5}$, Alan E. Hubbard ${ }^{2}$, Arthur Reingold ${ }^{2}$, John M. Colford, Jr. ${ }^{2}$

${ }^{1}$ Department of Epidemiology \& Population Health, Stanford University, Stanford, CA, United States

${ }^{2}$ Division of Epidemiology \& Biostatistics, University of California, Berkeley, CA, United States

${ }^{3}$ Francis I. Proctor Foundation, University of California, San Francisco, San Francisco, CA, United States

${ }^{4}$ Department of Ophthalmology, University of California, San Francisco, San Francisco, CA, United States

${ }^{5}$ Kaiser Permanente Vaccine Study Center, Oakland, CA, United States

Key words: influenza, influenza vaccination, school-located influenza vaccination

Corresponding author: Jade Benjamin-Chung, jadebc@stanford.edu, 259 Campus Drive HRP Redwood Building T152A, Stanford University, Stanford, CA 94305

\section{$\underline{\text { Abstract }}$}

Background: We measured the effectiveness of a city-wide school-located influenza vaccination (SLIV) program implemented in over 102 elementary schools in Oakland, California.

Methods: We conducted a retrospective cohort study among Kaiser Permanente Northern California (KPNC) members of all ages residing in either the intervention or a multivariatematched comparison site from September 2011 - August 2017. Outcomes included medically attended acute respiratory illness (MAARI), influenza hospitalization, and Oseltamivir prescriptions. We estimated difference-in-differences (DIDs) in 2014-15, 2015-16, and 2016-17 using generalized linear models and adjusted for race, ethnicity, age, sex, health plan, and language.

Results: Pre-intervention member characteristics were similar between sites. Among schoolaged children, SLIV was associated with lower Oseltamivir prescriptions per 1,000 (DIDs: -3.5 $(95 \% \mathrm{Cl}-5.5,-1.5)$ in $2015-16 ;-4.0(95 \% \mathrm{Cl}-6.5,-1.6)$ in $2016-17)$ but not with other outcomes. SLIV was associated with lower MAARI per 1,000 in adults $65+$ years $(2014-15:-13.2,95 \% \mathrm{CI}$ -23.2, -3.2; 2015-16: - 21.5, 95\% Cl-31.1, -11.9; 2016-17: -13.0, 95\% Cl-23.2, -2.9). There were few significant associations with other outcomes among adults.

Conclusions: A city-wide SLIV intervention was associated with lower Oseltamivir prescriptions in school-aged children and lower MAARI among people over 65 years, suggesting possible indirect effects of SLIV among older adults. 
medRxiv preprint doi: https://doi.org/10.1101/2021.05.03.21256546; this version posted May 4, 2021. The copyright holder for this preprint (which was not certified by peer review) is the author/funder, who has granted medRxiv a license to display the preprint in perpetuity.

It is made available under a CC-BY 4.0 International license.

Introduction

In the United States, seasonal influenza has been responsible for $140,000-590,000$

47 hospitalizations and 12,000 - 61,000 deaths annually since 2010 [1]. Children are responsible

48 for the majority of influenza transmission, and mathematical models suggest that vaccinating $50 \%-70 \%$ of school-aged children for influenza can produce herd immunity [2]. School-located influenza vaccination (SLIV) interventions may increase vaccine coverage

51 among schoolchildren and reduce influenza transmission community-wide [3]. SLIV is

52 associated with higher influenza vaccination coverage [4-13] and lower medically attended

53 acute respiratory illness (MAARI) [14], influenza-like illness [4] and laboratory-confirmed

54 influenza $[14,15]$ in schoolchildren. Some studies have reported indirect effects of SLIV among

55 non-school aged individuals, while others found none $[7,8,14,16-20]$. With the exception of one

56 study [4], prior SLIV evaluations have measured health outcomes using observational designs

57 that did not rigorously account for systematic differences between intervention and

58 comparison sites prior to intervention [5-8,13-20].

We previously reported the findings from a matched cohort study of a city-wide SLIV

60 program called Shoo the Flu that was implemented in a diverse, primarily low-income

61 population in Oakland, California [21]. The initial evaluation found higher vaccination coverage

62 and lower influenza hospitalization among non-elementary school aged individuals in the

63 intervention site.

65 between Shoo the Flu program on additional outcomes, including MAARI and Oseltamivir 
medRxiv preprint doi: https://doi.org/10.1101/2021.05.03.21256546; this version posted May 4, 2021. The copyright holder for this preprint (which was not certified by peer review) is the author/funder, who has granted medRxiv a license to display the preprint in perpetuity.

It is made available under a CC-BY 4.0 International license .

67 either the intervention or a matched comparison area. Using data from 2011 to 2017, we

68 estimated associations with SLIV among school-aged individuals and assessed potential indirect

69 effects in other age groups.

70 Methods

71 SLIV intervention

72 This study evaluated the Shoo the Flu intervention (www.shootheflu.org), which has

73 delivered free influenza vaccinations to schools in Oakland, California since 2014. The

74 intervention was delivered to children in all public and charter elementary schools in Oakland

75 Unified School District (OUSD, the "intervention district") and offered to all other charter and

76 private pre-schools and elementary schools in Oakland. OUSD has a diverse population of over

7726,000 elementary school students, and $>70 \%$ are low-income. From 2014-2017, Shoo the Flu

78 vaccinated $7,502-10,106$ students annually ( $22-28 \%$ of eligible students) in $102-138$ schools.

79 Each influenza season, 23-24\% of intervention participants reported KPNC health plan

80 membership. Additional intervention details are in the Supplement 1.

81 Study setting and population

KPNC is an integrated healthcare system that delivers care at 46 medical clinics and 21

83 hospitals operated by KPNC to approximately 4 million members. Members comprise at least

$8430 \%$ of the population and are representative of the race, ethnicity, and socioeconomic

85 distribution of Northern California, although very low-income individuals are under-

86 represented. Health care visits, diagnoses, prescriptions, immunizations, and laboratory results

87 are captured in KPNC's electronic medical record. Vaccines are offered free of charge to

88 members, and the date, injection site, and vaccine brand, lot, and dose of each vaccination at 
medRxiv preprint doi: https://doi.org/10.1101/2021.05.03.21256546; this version posted May 4, 2021. The copyright holder for this preprint (which was not certified by peer review) is the author/funder, who has granted medRxiv a license to display the preprint in perpetuity.

It is made available under a CC-BY 4.0 International license.

89 KPNC are recorded. Whether to test patients for influenza A or B using polymerase chain

90 reaction is at the discretion of KPNC clinicians.

$91 \quad$ All KPNC members who resided in the catchment areas of the intervention and

92 comparison districts from September 1, 2011 - August 31, 2017 and had no more than a one-

93 month gap in KPNC membership for each influenza season during the study period were

94 included in this study.

95 Vaccines

In 2014-15 and 2015-16, the intervention provided the live attenuated influenza vaccine

97 (LAIV) to students [22,23]. Students with LAIV contraindications were offered the trivalent

98 inactivated injectable influenza vaccine (IIV3), as were staff and teachers. Because LAIV

99 effectiveness in children was low in 2014-15 and 2015-16 [24-26], the intervention offered IIV4

100 to all participants following the Advisory Committee on Immunization Practices'

101 recommendation to use IIV for all children in 2016-17 [25].

102 Study design

103 We conducted a retrospective cohort study of KPNC health plan members who lived in

104 the catchment areas of the intervention district and a comparison district (West Contra Costa

105 Unified School District [WCCUSD]). We identified the comparison school district using a genetic

106 multivariate matching algorithm [27] to pair-match public elementary schools in the

107 intervention district and each candidate comparison district using pre-intervention school-level

108 characteristics (additional details in Supplement 2); detailed methods are available elsewhere

109 [21]. We selected WCCUSD as the comparison site because it had the smallest average

110 generalized Mahalanobis distance between paired schools [27]. 
medRxiv preprint doi: https://doi.org/10.1101/2021.05.03.21256546; this version posted May 4, 2021. The copyright holder for this preprint (which was not certified by peer review) is the author/funder, who has granted medRxiv a license to display the preprint in perpetuity.

It is made available under a CC-BY 4.0 International license .

\section{Program data}

KPNC electronic medical records did not include records for vaccinations administered

113 at locations other than KPNC. We therefore estimated the number of vaccinations delivered by

114 the program to KPNC members using data from the Shoo the Flu program, which tracks

115 vaccination counts using the number of vaccination consent forms collected from the parents

116 each year. Consent forms included information about insurance provider (e.g., KPNC or other

117 provider), allowing us to estimate the number of children vaccinated by Shoo the Flu who were

118 KPNC members.

119 Population and school district data

120 We obtained demographic information about the general population in study sites from

121 the U.S. 2010 Census using zip codes that overlapped with the intervention and comparison

122 school districts. We also obtained data about school district populations from the California

123 Department of Education for these zip codes for 2013.

\section{Outcomes}

125 Outcomes included medically attended acute respiratory illness (MAARI) (see

126 Supplement Table 1 for ICD-9 and ICD-10 codes), laboratory-confirmed influenza among tested

127 individuals, influenza hospitalization, and filled Oseltamivir prescriptions. Individuals

128 hospitalized with any of the following ICD-9-CM codes for otitis media and sinusitis (381-383,

$129461 x)$, upper respiratory tract illness (79x, 460, 462-463, 465, 487.1), and lower respiratory

130 tract illness $(464 x, 466 x, 480 x-487.0,490 x-496 x, 510 x-513 x, 515 x-516 x, 518 x$, and 786.1$)$ were

131 classified as having an influenza hospitalization. We defined laboratory-confirmed influenza as a

132 positive result from RT-PCR influenza diagnostic test. 
medRxiv preprint doi: https://doi.org/10.1101/2021.05.03.21256546; this version posted May 4, 2021. The copyright holder for this preprint (which was not certified by peer review) is the author/funder, who has granted medRxiv a license to display the preprint in perpetuity.

It is made available under a CC-BY 4.0 International license.

133

134

135

136

137 illness was greater than or equal to $2 \%$; it ended after two consecutive weeks with a percentage

138 under $2 \%$.

\section{$139 \quad$ Statistical analysis}

140 This study's pre-analysis plan and replication scripts are available at https://osf.io/rtsf2/.

142 outcome event in each season. We restricted analyses to influenza season, when the

143 intervention would be expected to affect influenza-related outcomes. Our primary pre-

144 specified parameter was mean difference-in-differences (DIDs) that compared the difference in

145 cumulative incidence during influenza season to that in three seasons prior to the intervention

146 (2011-2014) in each study group (the "pre-intervention DID”). Pre-intervention monthly

147 incidences of each outcome were consistent with the equal trends assumption (Supplement

148 Figure 2). DIDs remove time-invariant confounding but may be subject to time-dependent

149 confounding [28]. To account for this, we conducted a post-hoc alternative "pre-season DID"

150 analysis that compared the incidence in each influenza season to that in the period immediately

151 preceding each season (May - September). While the pre-season DID does not account for pre-

152 intervention differences, it is less subject to time-dependent confounding than the pre-

153 intervention DID. 
medRxiv preprint doi: https://doi.org/10.1101/2021.05.03.21256546; this version posted May 4, 2021. The copyright holder for this preprint (which was not certified by peer review) is the author/funder, who has granted medRxiv a license to display the preprint in perpetuity.

It is made available under a CC-BY 4.0 International license .

Models adjusted for available potential confounders with at least $5 \%$ prevalence in each

155 analysis; these included race, ethnicity, sex, mediCAL, subsidized KPNC health plan (proxy for

156 low socio-economic status), and primary language spoken. Enrollment in mediCAL or a

157 subsidized KPNC health plan varied by season; other variables were static. To minimize

158 empirical positivity violations from sparse data [29], we fit models only if the number of

159 outcome events per variable was $\geq 10$ and only fit adjusted models if the number of

160 observations within age, site, and outcome strata was $\geq 30$ [30]. We estimated $95 \%$ confidence

161 intervals using robust standard errors [31] to account for clustering at the household level.

162 Additional minor deviations from the plan are noted in Supplement 3, and additional analysis

163 details are in Supplement 4.

164 We stratified estimates by pre-specified age groups $(0-4,5-12,13-17,18-64$, and $65+$

165 years). Estimates among children 5-12 years represent "total effects" (including intervention

166 participants and non-participants) and estimates in other age groups represent "indirect effects"

167 among non-participants (Supplement Figure 1) [32]. Per our pre-analysis plan, we also stratified

168 estimates by individual vaccination status.

169 We performed a sensitivity analysis using alternative influenza seasons with influenza-

170 like-illness thresholds of $2.5 \%$ and $3 \%$ and the CDC influenza season definition (Week 40 to

171 Week 20 of the following year).

172 We pre-specified two negative control analyses to detect residual confounding or

173 selection bias [33,34]. First, we repeated our primary analysis with outcomes we did not expect

174 SLIV to affect (medically attended diarrhea and medically attended gastrointestinal illness) 
medRxiv preprint doi: https://doi.org/10.1101/2021.05.03.21256546; this version posted May 4, 2021. The copyright holder for this preprint (which was not certified by peer review) is the author/funder, who has granted medRxiv a license to display the preprint in perpetuity.

It is made available under a CC-BY 4.0 International license .

$175[33,34]$. We conducted a negative control time period analysis restricting to weeks outside

176 influenza season.

177 Ethical statement

178 This study was approved by the Committee for the Protection of Human Subjects at the

179 University of California, Berkeley (Protocol \# 2017-03-9741) and the KPNC Institutional Review

180 Board (Protocol \#CN-16-2825).

\section{Results}

182 Pre-intervention characteristics

183 The analyses included 175,628 to 269,266 individuals and 9,436,202 to $11,500,570$

184 person-weeks of observations per calendar year from 2011 to 2017 (Supplement Table 2).

185 During the influenza season, the number of person-weeks ranged from $3,069,633$ to $6,801,780$

186 per year.

187 Pre-intervention characteristics were similar among individuals in the intervention and

188 comparison sites (Table 1). In the intervention site vs. the comparison site, there were fewer

189 Asian (14.2\% vs. 19.3\%) and Hispanic (30.5\% vs. $43.0 \%$ ) individuals and more Black / African

190 American (28.2\% vs. $20.2 \%$ ) and White individuals (35.2\% vs. $29.5 \%$ ). The proportion of

191 individuals enrolled in MediCAL was lower in the intervention site vs. the comparison site (4.4\%

192 vs. $6.7 \%)$.

193 Characteristics were similar overall between the study population, general population

194 (all individuals residing in zip codes overlapping with the study site) and school district

195 population (Supplement Table 3). The percentage of individuals in the study population who

196 were Hispanic was lower than in the general population (31-43\% vs. 39-54\%). The percentage 
medRxiv preprint doi: https://doi.org/10.1101/2021.05.03.21256546; this version posted May 4, 2021. The copyright holder for this preprint (which was not certified by peer review) is the author/funder, who has granted medRxiv a license to display the preprint in perpetuity.

It is made available under a CC-BY 4.0 International license .

197 of the study population whose primary language spoken was not English was also lower (12-

198 14\%) than in the general population (40-47\%) and school district population (38-43\%).

199 Influenza vaccination

200 Among the study population, influenza vaccination coverage was lower in the

201 intervention site than the comparison site across age groups and years. Prior to the

202 intervention, vaccination coverage was also consistently lower in the intervention site than the

203 comparison site (Supplement Table 4); this difference was larger during the intervention period

204 for children 5-12 years (Supplement Figure 3). Including all vaccinations (administered by both

205 KPNC and the SLIV intervention), coverage was 8-11\% higher in the intervention site than the

206 comparison site during the intervention period (Figure 1). Across all years, KPNC mostly

207 administered IIV to elementary school aged children in the study (Supplement Figure 4).

208 Cumulative incidence of influenza-related outcomes

209 The cumulative incidence of MAARI ranged from 0.14 to 0.58 per season by age and was

210 highest among children 0-4 years (Supplement Figure 5). Very few individuals were tested for

211 influenza ( $<1 \%$ of individuals per season), and the proportion who tested positive varied

212 substantially by age, season, and site. The incidence of influenza hospitalization was low in all

213 age groups, with the highest incidence among adults $\geq 65$ years (range: 0.053 to 0.097 per

214 season). The incidence of filled Oseltamivir prescriptions ranged from 0.0007 to 0.0134 per

215 season.

216 Associations among elementary school aged children

217 Overall, the intervention was not associated with MAARI in elementary school aged

218 children except for in 2015-16, when it was associated with lower MAARI when accounting for 
medRxiv preprint doi: https://doi.org/10.1101/2021.05.03.21256546; this version posted May 4, 2021. The copyright holder for this preprint (which was not certified by peer review) is the author/funder, who has granted medRxiv a license to display the preprint in perpetuity.

It is made available under a CC-BY 4.0 International license.

219 pre-season differences between sites (Figure 2, Supplement Figure 6, Supplement Table 5).

220 Among elementary school aged children, in 2016-17 the unadjusted pre-intervention DID in the

221 cumulative incidence of filled Oseltamivir prescriptions per 1,000 was $-3.5(95 \% \mathrm{Cl}-5.5,-1.5)$ in

$222 \quad 2015-16$ and $-4.0(95 \% \mathrm{Cl}-6.5,-1.6)$ in 2016-17; there was no association in 2014-15. These

223 associations were attenuated towards the null in the analysis accounting for pre-season

224 differences. There was no association with influenza hospitalization elementary school aged

225 children.

226 Associations among non-elementary school aged individuals

227 DIDs indicated no association between the intervention and laboratory-confirmed

228 influenza in most program years and age groups among non-elementary school aged individuals

229 (Supplement Table 5). In intervention vs. comparison sites, MAARI per 1,000 was lower among

230 adults 65 years or older when accounting for pre-intervention differences (2014-15: -13.2, 95\%

$231 \mathrm{Cl}-23.2,-3.2 ;$ 2015-16: -21.5, 95\% Cl-31.1, -11.9; 2016-17: -13.0, 95\% Cl-23.2, -2.9) (Figure 2).

232 When accounting for pre-season differences, DIDs indicated slightly stronger protective

233 associations with MAARI for most age groups and seasons (Supplement Figure 6). DIDs for filled

234 Oseltamivir prescriptions per 1,000 were lower among adults $18-64$ years in $2016-17(-1.6,95 \%$

$235 \mathrm{Cl}-2.5,-0.7)$; results were similar when accounting for pre-season differences. DIDs indicated a

236 higher incidence of influenza hospitalization among adults 18 years or older in 2014-15 and

237 adults 18-64 years in 2015-16. Pre-season DIDs displayed a different pattern for adults:

238 associations were null for adults 18 years or older except for adults 65 years or older in 2015-16,

239 when the association was protective. 
medRxiv preprint doi: https://doi.org/10.1101/2021.05.03.21256546; this version posted May 4, 2021. The copyright holder for this preprint (which was not certified by peer review) is the author/funder, who has granted medRxiv a license to display the preprint in perpetuity.

It is made available under a CC-BY 4.0 International license .

For all ages, the results of adjusted models were similar to those of unadjusted models

241 (Supplement Table 6). Results stratified by vaccination status were similar overall to the

242 primary analysis (Supplement Tables 7-8).

243 Negative control analyses

Analyses using non-influenza outcomes (medically attended diarrhea and medically

245 attended gastrointestinal illness) produced primarily null associations (Supplement Table 9).

246 Analyses restricted to weeks outside of influenza season produced almost exclusively null

247 results (Supplement Table 10).

248 Sensitivity analyses using alternative influenza season definitions

249 Results were similar when using alternative influenza season definitions (Supplement

250 Figure 7). For outcomes with sufficient data to restrict to the peak week of influenza, results

251 suggested no association with the intervention.

\section{Discussion}

In this three-year evaluation of a city-wide SLIV intervention, among elementary school

254 aged children, SLIV was associated with lower Oseltamivir prescriptions but not with MAARI,

255 laboratory-confirmed influenza, or influenza hospitalization. We found some evidence of

256 indirect effects in non-elementary school aged individuals: SLIV was associated with lower

257 MAARI among adults 65 years or older and lower Oseltamivir prescriptions among pre-school

258 children in 2015-16.

259 Some prior observational studies of SLIV programs have also reported indirect effects of

260 SLIV on MAARI and related outcomes [14,18-20], while others have reported non-significant or

261 null results $[7,8,13,16,17]$. These studies did not use analytic methods to account for 
medRxiv preprint doi: https://doi.org/10.1101/2021.05.03.21256546; this version posted May 4, 2021. The copyright holder for this preprint (which was not certified by peer review) is the author/funder, who has granted medRxiv a license to display the preprint in perpetuity.

It is made available under a CC-BY 4.0 International license .

262 differences between intervention and comparison sites prior to intervention or outside of

263 influenza season. The one prior study that did so found no association between SLIV and

264 hospitalization among the elderly [16]. The present study included three years of pre-

265 intervention data and used a DID approach to adjust for pre-intervention differences; thus, our

266 findings likely have higher internal validity than prior observational SLIV evaluations.

267 Vaccine effectiveness varied substantially during the study period. In 2014-15 all vaccine

268 formulations had low effectiveness due to a poor strain match [24]. In 2015-16, the LAIV had

269 poor vaccine effectiveness, but the IIV was moderately effective [26]. In 2016-17, only IIV was

270 available and it was moderately effective [35]. These differences and varying vaccine coverage

271 by the SLIV intervention each year [21] contribute to heterogeneous estimates across seasons. SLIV may increase vaccination coverage among children who would not otherwise be

273 vaccinated and/or shift vaccination location from doctor's offices to schools. If SLIV merely

274 shifts vaccination location, it would not be expected to reduce influenza. In this study, SLIV

275 appeared to both increase vaccination and shift vaccination location among elementary school

276 aged children. The proportion of 5-12 year-olds vaccinated by their medical provider was lower

277 in the intervention site than the comparison site, but the proportion vaccinated by KPNC or SLIV

278 combined was higher. This finding is consistent with our prior evaluation of Shoo the Flu [21]

279 and evaluations of other SLIV interventions that also increased vaccination coverage [4-13].

280 Our finding that SLIV was associated with higher influenza hospitalization in adults in

281 some years was unexpected. This finding contrasts with the prior Shoo the Flu evaluation,

282 which found that SLIV was associated with lower influenza hospitalization in non-elementary

283 age groups [21]. Other prior SLIV evaluations have had conflicting findings with regard to 
medRxiv preprint doi: https://doi.org/10.1101/2021.05.03.21256546; this version posted May 4, 2021. The copyright holder for this preprint (which was not certified by peer review) is the author/funder, who has granted medRxiv a license to display the preprint in perpetuity. It is made available under a CC-BY 4.0 International license .

indirect effects on hospitalization $[7,8,13,16,17]$. One cluster-randomized trial reported a higher

285 hospitalization rate in SLIV participants, but when stratifying by child vaccination status, the

286 finding was not significant [4]. In a post-hoc analysis accounting for pre-season differences

287 between sites, which may better account for time-dependent confounding than our primary

288 analysis, associations with hospitalization were null or protective.

This study is subject to several limitations. First, its observational design may be subject

290 to unmeasured confounding. In a small number of negative control outcome and time period

291 analyses, unexpected associations suggest that unmeasured confounding occurred. The DID

292 analysis controlled for time-invariant confounding [28], but unmeasured time-varying

293 confounding may have occurred. Common confounders of influenza vaccine studies are age,

294 calendar time, and health status [36]. Our analysis stratified by age and season, but baseline

295 health status was not available. Second, differences in sociodemographic characteristics

296 between the study population and the general and student populations in the study sites limit

297 the generalizability of our findings. Third, many outcomes were rare, precluding formal analyses

298 for some outcomes and limiting statistical power, which may have contributed to null findings.

299 Finally, we did not have complete vaccination information about each individual. It was not

300 possible to link data from the California Immunization Registry with KPNC member data. This

301 limitation underscores the need for more robust vaccine registries [37]. Notably, the limitations

302 of this study apply to most prior SLIV evaluations, which primarily have been observational and

303 leveraged existing data. We expect that among individuals not targeted by the SLIV intervention,

304 influenza vaccinations outside KPNC were infrequent, so this limitation is unlikely to have

305 meaningfully impacted study findings. 
medRxiv preprint doi: https://doi.org/10.1101/2021.05.03.21256546; this version posted May 4, 2021. The copyright holder for this preprint (which was not certified by peer review) is the author/funder, who has granted medRxiv a license to display the preprint in perpetuity.

It is made available under a CC-BY 4.0 International license.

307 intervention. This study supports our prior finding that SLIV both increased vaccination

308 coverage and shifted vaccination location and provides additional evidence that SLIV was

309 associated with lower Oseltamivir prescriptions in school aged children and lower MAARI in

310 older adults.

311

312 
medRxiv preprint doi: https://doi.org/10.1101/2021.05.03.21256546; this version posted May 4, 2021. The copyright holder for this preprint (which was not certified by peer review) is the author/funder, who has granted medRxiv a license to display the preprint in perpetuity.

It is made available under a CC-BY 4.0 International license.

\section{Funding}

314 This work was supported by a grant from the Flu Lab (https://theflulab.org/) to the University of

315 California, Berkeley (Grant number: 20142281; PI: AR).

\section{Acknowledgements}

317 The authors would like to acknowledge Kristin Goddard, Karen Nunley, and Berwick Chan at

318 Kaiser Permanente Northern California and Kate Holbrook at Alameda County Public Health

319 Department for their contributions to data collection.

320 NPK reports research support from Protein Science (Sanofi Pasteur) and Sanofi Pasteur for

321 unrelated influenza vaccine studies and from GlaxoSmithKline, Merck \& Co, and Pfizer for

322 unrelated studies. JBC, BFA, KM, CJK, AN, NNP, SD, AS, AEH, AR, JMC report no conflicts.

\section{References}

324 1. Centers for Disease Control and Prevention. Burden of Influenza. 2020. Available at:

325 https://www.cdc.gov/flu/about/burden/index.html. Accessed 27 July 2020.

326 2. Longini IM. A Theoretic Framework to Consider the Effect of Immunizing Schoolchildren

327 Against Influenza: Implications for Research. Pediatrics 2012; 129:S63-S67.

328 3. Gaglani MJ. Editorial Commentary: School-Located Influenza Vaccination: Why Worth the

$329 \quad$ Effort? Clin Infect Dis 2014; 59:333-335.

330 4. King JC, Stoddard JJ, Gaglani MJ, et al. Effectiveness of School-Based Influenza Vaccination.

$331 \quad$ N Engl J Med 2006; 355:2523-2532. 
medRxiv preprint doi: https://doi.org/10.1101/2021.05.03.21256546; this version posted May 4, 2021. The copyright holder for this preprint (which was not certified by peer review) is the author/funder, who has granted medRxiv a license to display the preprint in perpetuity.

It is made available under a CC-BY 4.0 International license .

5. Davis MM, King JC, Moag L, Cummings G, Magder LS. Countywide School-Based Influenza Immunization: Direct and Indirect Impact on Student Absenteeism. Pediatrics 2008;

6. Kjos SA, Irving SA, Meece JK, Belongia EA. Elementary School-Based Influenza Vaccination: Evaluating Impact on Respiratory Illness Absenteeism and Laboratory-Confirmed Influenza.

7. Pebody RG, Green HK, Andrews N, et al. Uptake and impact of vaccinating school age children against influenza during a season with circulation of drifted influenza A and B strains, England, 2014/15. Eurosurveillance 2015; 20.

8. Pebody RG, Green HK, Andrews N, et al. Uptake and impact of a new live attenuated influenza vaccine programme in England: early results of a pilot in primary school-age

9. Szilagyi PG, Schaffer S, Rand CM, et al. School-Located Influenza Vaccinations: A children, 2013/14 influenza season. Eurosurveillance 2014; 19:20823.

10. Szilagyi PG, Schaffer S, Rand CM, et al. Impact of elementary school-located influenza vaccinations: A stepped wedge trial across a community. Vaccine 2018 ; 36:2861-2869. Clinics at School Raise Vaccination Rates? J Sch Health 2019; 89:1004-1012. 
medRxiv preprint doi: https://doi.org/10.1101/2021.05.03.21256546; this version posted May 4, 2021. The copyright holder for this preprint (which was not certified by peer review) is the author/funder, who has granted medRxiv a license to display the preprint in perpetuity.

It is made available under a CC-BY 4.0 International license .

350 12. Humiston SG, Schaffer SJ, Szilagyi PG, et al. Seasonal Influenza Vaccination at School: A

351 Randomized Controlled Trial. Am J Prev Med 2014; 46:1-9.

352 13. Pebody RG, Sinnathamby MA, Warburton F, et al. Uptake and impact of vaccinating primary

353 school-age children against influenza: experiences of a live attenuated influenza vaccine

354 programme, England, 2015/16. Eurosurveillance 2018; 23:1700496.

355 14. Glezen WP, Gaglani MJ, Kozinetz CA, Piedra PA. Direct and Indirect Effectiveness of

356 Influenza Vaccination Delivered to Children at School Preceding an Epidemic Caused by 3

357 New Influenza Virus Variants. J Infect Dis 2010; 202:1626-1633.

358 15. Pannaraj PS, Wang H-L, Rivas H, et al. School-Located Influenza Vaccination Decreases

359 Laboratory-Confirmed Influenza and Improves School Attendance. Clin Infect Dis 2014;

$360 \quad 59: 325-332$.

361 16. McBean M, Hull HF, O’Connor H. Possible Herd Immunity in the Elderly Following the

362 Vaccination of School Children with Live, Attenuated Trivalent Influenza Vaccine: A Person-

363 Level Analysis. Procedia Vaccinol 2011; 4:59-70.

364 17. Hull HF, McBean AM, Caldwell D, O'Connor H. Assessing Herd Immunity in the Elderly

365 Following the Vaccination of School Children with Live Attenuated Trivalent Influenza

366 Vaccine (LAIV): A County-Level Analysis. Procedia Vaccinol 2010; 2:90-98.

367 18. Tran $\mathrm{CH}$, Sugimoto JD, Pulliam JRC, et al. School-Located Influenza Vaccination Reduces

368 Community Risk for Influenza and Influenza-Like Illness Emergency Care Visits. PLoS ONE

$369 \quad$ 2014; 9:e114479. 
medRxiv preprint doi: https://doi.org/10.1101/2021.05.03.21256546; this version posted May 4, 2021. The copyright holder for this preprint (which was not certified by peer review) is the author/funder, who has granted medRxiv a license to display the preprint in perpetuity.

It is made available under a CC-BY 4.0 International license .

370 19. Piedra PA, Gaglani MJ, Kozinetz CA, et al. Herd immunity in adults against influenza-related

371 illnesses with use of the trivalent-live attenuated influenza vaccine (CAIV-T) in children.

$372 \quad$ Vaccine 2005; 23:1540-1548.

373 20. Piedra PA, Gaglani MJ, Kozinetz CA, et al. Trivalent Live Attenuated Intranasal Influenza

374 Vaccine Administered During the 2003-2004 Influenza Type A (H3N2) Outbreak Provided

375 Immediate, Direct, and Indirect Protection in Children. Pediatrics 2007; 120:e553-e564.

376 21. Benjamin-Chung J, Arnold BF, Kennedy CJ, et al. Evaluation of a city-wide school-located

377 influenza vaccination program in Oakland, California with respect to vaccination coverage,

378 school absences, and laboratory-confirmed influenza: a matched cohort study. PLOS Med

$379 \quad 2020 ; 17: e 1003238$.

22. Grohskopf LA, Olsen SJ, Sokolow LZ, et al. Prevention and control of seasonal influenza with vaccines: recommendations of the Advisory Committee on Immunization Practices (ACIP) -United States, 2014-15 influenza season. Morb Mortal Wkly Rep 2014; 63:691-697.

23. Grohskopf LA, Sokolow LZ, Olsen SJ, Bresee JS, Broder KR, Karron RA. Prevention and Control of Influenza with Vaccines: Recommendations of the Advisory Committee on Immunization Practices, United States, 2015-16 Influenza Season. Morb Mortal Wkly Rep the United States by Vaccine Type. Clin Infect Dis 2016; 63:1564-1573. 
medRxiv preprint doi: https://doi.org/10.1101/2021.05.03.21256546; this version posted May 4, 2021. The copyright holder for this preprint (which was not certified by peer review) is the author/funder, who has granted medRxiv a license to display the preprint in perpetuity. It is made available under a CC-BY 4.0 International license .

25. Grohskopf LA, Sokolow LZ, Broder KR, et al. Prevention and Control of Seasonal Influenza with Vaccines: Recommendations of the Advisory Committee on Immunization Practices United States, 2016-17 Influenza Season. Morb Mortal Wkly Rep 2016; 65:1-54.

26. Jackson ML, Chung JR, Jackson LA, et al. Influenza Vaccine Effectiveness in the United States during the 2015-2016 Season. N Engl J Med 2017; 377:534-543.

27. Diamond A, Sekhon JS. Genetic Matching for Estimating Causal Effects: A General Multivariate Matching Method for Achieving Balance in Observational Studies. Rev Econ

28. Wing C, Simon K, Bello-Gomez RA. Designing Difference in Difference Studies: Best Practices Stat 2013; 95:932-945.

29. Petersen ML, Porter KE, Gruber S, Wang Y, van der Laan MJ. Diagnosing and responding to violations in the positivity assumption. Stat Methods Med Res 2010; $21: 31-54$.

30. Peduzzi P, Concato J, Kemper E, Holford TR, Feinstein AR. A simulation study of the number of events per variable in logistic regression analysis. J Clin Epidemiol 1996; 49:1373-1379.

31. Freedman DA. On The So-Called "Huber Sandwich Estimator" and "Robust Standard Errors". Am Stat 2006; 60:299-302. study designs and methodological considerations. Int J Epidemiol 2018; 47:332-347. 
medRxiv preprint doi: https://doi.org/10.1101/2021.05.03.21256546; this version posted May 4, 2021. The copyright holder for this preprint (which was not certified by peer review) is the author/funder, who has granted medRxiv a license to display the preprint in perpetuity.

It is made available under a CC-BY 4.0 International license .

407 33. Lipsitch M, Tchetgen ET, Cohen T. Negative controls: a tool for detecting confounding and 408 bias in observational studies. Epidemiol Camb Mass 2010; 21:383-388.

409 34. Arnold BF, Ercumen A, Benjamin-Chung J, Colford JM. Negative Controls to Detect Selection

$410 \quad$ Bias and Measurement Bias in Epidemiologic Studies: Epidemiology 2016; 27:637-641.

411 35. Centers for Disease Control. Seasonal Influenza Vaccine Effectiveness, 2016-2017. 2019.

$412 \quad$ Available at: https://www.cdc.gov/flu/vaccines-work/2016-2017.html. Accessed 14 June

4132019.

414 36. Ainslie KEC, Haber M, Orenstein WA. Challenges in estimating influenza vaccine

415 effectiveness. Expert Rev Vaccines 2019; 18:615-628.

416 37. Benjamin-Chung J, Reingold A. Measuring the Success of the US COVID-19 Vaccine

417 Campaign - It's Time to Invest in and Strengthen Immunization Information Systems. Am J

$418 \quad$ Public Health 2021; :e1-e3. 
medRxiv preprint doi: https://doi.org/10.1101/2021.05.03.21256546; this version posted May 4, 2021. The copyright holder for this preprint (which was not certified by peer review) is the author/funder, who has granted medRxiv a license to display the preprint in perpetuity.

It is made available under a CC-BY 4.0 International license .

422 Table 1. Pre-intervention characteristics of the study population in each site

423

\begin{tabular}{|c|c|c|}
\hline & $\begin{array}{c}\text { Intervention } \\
\%(95 \% \mathrm{Cl})\end{array}$ & $\begin{array}{c}\text { Comparison } \\
\%(95 \% \mathrm{Cl})\end{array}$ \\
\hline \multicolumn{3}{|l|}{ Age (years) } \\
\hline Under 5 & $5.2(5.1,5.4)$ & $5.5(5.4,5.7)$ \\
\hline $5-14$ & $10.6(10.4,10.8)$ & $13.5(13.3,13.8)$ \\
\hline $15-17$ & $3.1(3.0,3.2)$ & $4.2(4.0,4.3)$ \\
\hline $18-64$ & $66.0(65.6,66.4)$ & $62.2(61.7,62.6)$ \\
\hline 65 and over & $15.0(14.7,15.4)$ & $14.6(14.1,15.0)$ \\
\hline \multicolumn{3}{|l|}{ Sex } \\
\hline Female & $53.8(53.5,54.0)$ & $52.8(52.5,53.1)$ \\
\hline Male & $46.2(45.9,46.5)$ & $47.2(46.9,47.5)$ \\
\hline \multicolumn{3}{|l|}{ Race } \\
\hline Asian & $14.2(13.7,14.6)$ & $19.3(18.9,19.8)$ \\
\hline Black / African American & $28.2(27.7,28.8)$ & $20.2(19.5,20.8)$ \\
\hline Hawaiian / Pacific Islander & $0.5(0.4,0.5)$ & $0.9(0.8,1.0)$ \\
\hline Native American & $0.4(0.3,0.4)$ & $0.4(0.4,0.5)$ \\
\hline Multiracial & $1.2(1.1,1.2)$ & $1.1(1.0,1.2)$ \\
\hline White & $35.2(34.7,35.7)$ & $29.5(29.0,30.1)$ \\
\hline Race not recorded & $20.4(19.9,20.8)$ & $28.5(28.0,29.1)$ \\
\hline Hispanic Ethnicity ${ }^{a}$ & $30.5(29.9,31.2)$ & $43.0(42.2,43.7)$ \\
\hline MediCAL enrollee & $4.4(4.2,4.6)$ & $6.7(6.4,7.0)$ \\
\hline Subsidized KPNC insurance & $1.0(0.9,1.1)$ & $1.5(1.4,1.7)$ \\
\hline Primary language is not English ${ }^{b}$ & $12.0(11.7,12.4)$ & $14.1(13.7,14.6)$ \\
\hline
\end{tabular}

424

Includes data for 101,761 Kaiser Permanente Northern California patients between September 1, 2013 and August $31,2014$.

$425{ }^{a}$ Includes data for 61,847 Kaiser Permanente Northern California with recorded Hispanic ethnicity.

426 ' Includes data for 100,492 Kaiser Permanente Northern California with recorded primary language. 
medRxiv preprint doi: https://doi.org/10.1101/2021.05.03.21256546; this version posted May 4, 2021. The copyright holder for this preprint (which was not certified by peer review) is the author/funder, who has granted medRxiv a license to display the preprint in perpetuity.

It is made available under a CC-BY 4.0 International license .

Figure 1. Percentage of elementary school aged study population vaccinated for influenza by

"Vaccination by KPNC - Comparison" includes influenza vaccinations delivered by KPNC in the comparison site. "Vaccination by KPNC - Intervention" includes influenza vaccinations delivered by KPNC in the intervention site. "Vaccination by Shoo the Flu" includes influenza vaccinations delivered by the Shoo the Flu intervention in the intervention site. The percentage vaccinated for influenza does not include vaccinations that were not delivered by KPNC or Shoo the Flu. The denominator is KPNC patients aged 5-12 years. 
medRxiv preprint doi: https://doi.org/10.1101/2021.05.03.21256546; this version posted May 4, 2021. The copyright holder for this preprint (which was not certified by peer review) is the author/funder, who has granted medRxiv a license to display the preprint in perpetuity.

It is made available under a CC-BY 4.0 International license .

440
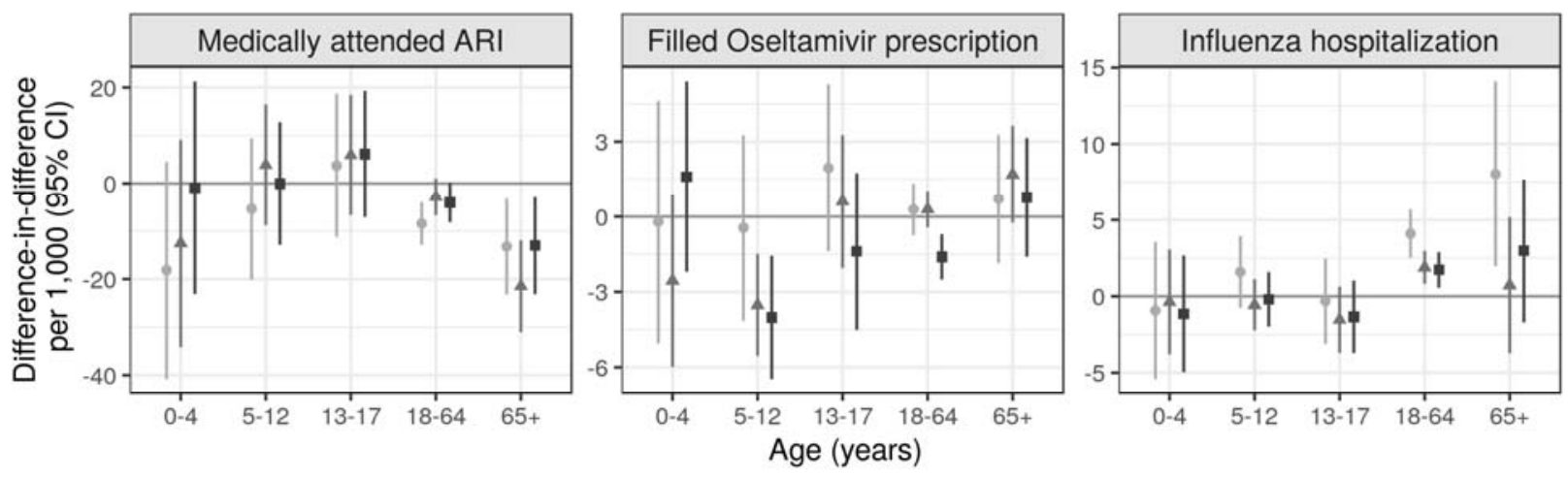

Influenza Season

2016-17

\section{Figure 2. Difference-in-differences accounting for pre-intervention differences}

Difference-in-difference in cumulative incidence of each outcome during each influenza season comparing the difference in mean outcome in each district in an intervention year compared to the three pre-intervention years (2011-2013). Difference-in-difference parameters remove any time-invariant differences between groups (measured or unmeasured). Parameters were estimated using a generalized linear model without covariate adjustment due to data sparsity. Standard errors accounted for clustering at the household level. Estimates in children 5-12 years measure total effects and estimates in other age groups measure indirect effects. Analyses were restricted to influenza season defined based the percentage of medical visits for influenza-like illness in California as reported by the California Department of Public Health. Influenza season started when there were at least 2 consecutive weeks in which the percentage of medical visits for influenza-like illness exceeded $2 \%$, and the season ended when there were at least two consecutive weeks in which the percentage was less than or equal to $2 \%$. 